\title{
Spectrophotometric Determination of Zinc in Pharmaceutical Medication Samples Using 8-Hydroxyquinoline Reagent
}

\author{
Safaa Sabri Najim ${ }^{1}$, Maha Abid Al-Hussian Hameed ${ }^{2}$, Mundher Abdulhasan Al-Shakban ${ }^{3}$, Tahseen Saddam Fandi ${ }^{1}$ \\ ${ }^{1}$ Chemistry Department, College of Science' Misan University- Maysan, Iraq \\ ${ }^{2}$ Department of Applied Marine Science, College of Marine Science, University of Basrah- Basra, Iraq \\ ${ }^{3}$ Physics Department, College of Science, Misan University- Maysan, Iraq \\ Correspondence: Safaa Sabri Najim, Chemistry Department, College of Science'Misan University- Maysan, Iraq.
}

Received: September 1, 2019 Accepted: October 17, 2019 Online Published: October 20, 2019

doi:10.5539/ijc.v12n1p29

URL: https://doi.org/10.5539/ijc.v12n1p29

\begin{abstract}
Simple, rapid, cheap and sensitive spectrophotometric method has been described for the determination of zinc in pharmaceutical samples. The method is based on the formation of zinc- 8-Hydroxy quinoline chelate, the maximum absorption $\left(\lambda_{\max }\right)$ at $384 \mathrm{~nm}$. The method obeyed Beer's law in the range $1-5 \mu \mathrm{g} / \mathrm{mL}$ and the corresponding molar absorptivity value is $0.01578 \times 10^{3} \mathrm{~L} \cdot \mathrm{mol}^{-1} \cdot \mathrm{cm}^{-1}$. The Sandell sensitivity values of limits of detection (LOD) and quantification (LOQ) was $0.381 \mu \mathrm{g} / \mathrm{mL}$ and $1.156 \mu \mathrm{g} / \mathrm{mL}$ respectively. The recovery percentage of zinc was found $98.00 \%, 98.96 \%, 99.91 \%, 97.50 \%, 98.5 \%$ and $99.30 \%$ for (Capsule-13 mg), (Tablet-20 mg), (Tablet-40 $\mathrm{mg}$ ),(Capsule-50 mg), (Capsule-50 mg) and (insulin vial-0.025 mg) respectively. All variable parameters has been optimized according to ICH guidelines. The limiting concentrations of some cations for interference by $\mathrm{Mn}$ (II), $\mathrm{Fe}(\mathrm{II})$, $\mathrm{Co}(\mathrm{II}), \mathrm{Ni}(\mathrm{II}), \mathrm{Cu}(\mathrm{II}), \mathrm{Cd}(\mathrm{II}), \mathrm{Sn}(\mathrm{II}), \mathrm{Pb}(\mathrm{II}), \mathrm{Mg}(\mathrm{II}), \mathrm{Ca}(\mathrm{II})$ and $\mathrm{Ba}(\mathrm{II})$ are reported. The method accuracy was established by comparison with conventional flame atomic absorption spectrometric method by using $\mathrm{t}$-test, $\mathrm{t}_{\mathrm{tab} .}=2.571, \mathrm{t}_{\text {cal. }}=0.3231$ at $95 \%$ confidence level, indicating the absence of systematic errors.
\end{abstract}

Keywords: spectrophotometric, zinc, pharmaceutical medication, 8-hydroxyquinoline chelate, insulin

\section{Introduction}

In biology, Zinc is as ordinary as iron (Williams, Phil, \& F.R.S., 1984). It is a necessary trace element and plays a vital role in normal growth and development (Favier \& Hininger-Favier, 2005), many biological functions such as cellular integrity, protein synthesis and nucleic acid metabolism need Zinc. It plays important role in brain development and also as an antioxidant (Takeda, 2000) and (Tate, Miceli, \& Newsome, 1999) Zinc is a fundamental micronutrient (Maret \& Sandstead, 2006). It has a connection with diseases, chronic kidney disease (Neto et al., 2016), HIV infection (Siberry, Ruff \& Black, 2002), diabetics (Jansen, Karges \& Rink, 2009) and cancer risk (Emily, 2004). Zinc is the most familiar element in multimineral and multivitamin preparations with microelements. In biological material, pharmaceutical preparations, and food, marked with the use of, spectrophotometric, (Sabel, Neureuther \& Siemann, 2010) and, (Adi et al., 2016), spectrofluorometric (Takahira, Satoshi \& Hitoshi, 2003), atomic absorption spectrometry(Sołtyk, et al., 2000), atomic absorption spectrophotometry method for determination of zinc in insulin(Ata et al., 2015), capillary electrophoresis (Wittrisch, et al., 1997), electrochemicals(Kumar, 1997) and thin layer chromatography(Manciri, \& Zuanon-Netto,1998) methods.

In pharmaceutical preparations Zn-II has been marked spectrophotometrically, mostly with the employ of azo derivatives (Bhalotra, \& Duri, 1999) and (Korn, et al., 1999).

Stable bidentate ligand chelate synthesized with zinc ion, 8-Hydroxyquinoline has atom that replaced by zinc ion and heterocyclic nitrogen atom, which forms with this ion a five membered ring (Kai, et al., 1985) as shown in Fig.1.

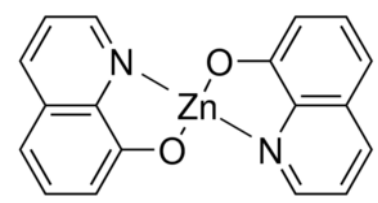

Figure 1. Zn-Bidentate chelate 
The target of the study is to find out the validity of (system suitability, accuracy, linearity and precision) of the spectrophotometric method for determination of zinc in pharmaceutical samples by using 8-Hydroxyqinoline reagent.

\section{Materials and Methods}

\section{Instrumentation}

A Shimadzu (UV-1800) double beam UV/VIS spectrophotometer using $10 \mathrm{~mm}$ quartz cells and Aurora (Model -AI 1200) flame atomic absorption spectrometer was used, the spectroscopic setting were; band width $0.2 \mathrm{~nm}$; deuterium $\left(\mathrm{D}_{2}\right)$ for background correction; integration time was 5 second; the current of the lamp was $5.0 \mathrm{~mA}$ lamp and the analyte was detected at $213.9 \mathrm{~nm}$.

\section{Reagent and solutions}

All the chemicals used were of analytical reagent grade or highest available purity, deionized water was used. Glassware were cleaned by soaking in acidified solution of potassium permanganate followed by washing with concentrated nitric acid and rinsed with deionized water several times. The chemicals were used without further purification.

\section{8-Hydroxyquinoline solution $\left(\mathrm{C}_{9} \mathrm{H}_{7} \mathrm{NO}\right),\left(2 \times 10^{-3} \mathrm{M}\right)$}

Prepared by dissolving $0.0290 \mathrm{~g}$ of 8 -Hydroxyquinolin (8-HQ) in a volumetric $100 \mathrm{ml}$ filled to the mark with ethanol of $99.2 \%$. More diluted solutions were prepared as needed.

\section{Stock solution of Zinc}

Stock solution of Zinc (1000 $\mathrm{mg} \mathrm{L}^{-1}$ ) was purchased from Scharlau (Darmstadt, Germany).Working standard solutions were prepared daily by sequential dilution of the stock solution with deionized water.

\section{Ammonium hydroxide solution}

A diluted solution of ammonium was prepared in volumetric flask $100 \mathrm{ml}$ with adding $10 \mathrm{~mL}$ of concentrated ammonium solution (28-30\% A.C.S grade) to deionized water.

\section{Sulfuric acid solution}

A solution $0.0001 \mathrm{M}$ of sulfuric acid was prepared in a volumetric flask $100 \mathrm{~mL}$ by serial dilution of concentrated sulfuric acid (98\%) with deionized water.

\section{General procedure}

A volume of $1-5 \mathrm{ml}$ of standard solution containing $1-5 \mu \mathrm{g}$ of zinc in $10 \mathrm{~mL}$ volumetric flask was mixed with (preferably) $5.5 \mathrm{~mL} 8-\mathrm{HQ}\left(1.1 \times 10^{-3} \mathrm{M}\right)$ followed by addition of $0.1-1 \mathrm{~mL}$ (preferably $\left.0.6 \mathrm{ml}\right)$ of $1 \times 10^{-4} \mathrm{M}$ sulfuric acid. After 1 minute $1 \mathrm{~mL}$ of ethanol was added, the mixture was diluted up to the mark with deionized water. The absorbance was measured after waiting for 15 minutes at $384 \mathrm{~nm}$ against a corresponding reagent blank. The zinc content in the samples was determined by using the linearity equation of calibration curve.

\section{Procedure for commercial samples}

Ten tablets and capsules were weighed accurately and ground into a fine powder. Tablet and capsule powder equivalent to $200 \mathrm{mg}$ was accurately weighted and taken to a beaker and digested according to Ahmed method(Ahmed, et al., 2010). $10 \mathrm{~mL}$ of concentrated nitric acid was added and to dryness, $10 \mathrm{ml}$ of $20 \%(\mathrm{v} / \mathrm{v}$ ) of sulfuric acid solution added. The volume was became $2.5 \mathrm{~mL}$ by heating on a hotplate and cooled to room temperature. The solution was neutralized with diluted ammonium solution, the resulting solution filtrated and transferred quantitatively to $50 \mathrm{~mL}$ volumetric flask and filled with deionized water to the mark. Humulin N Vial $(5 \mathrm{~mL}, 100 \mathrm{IU} / \mathrm{ml})$ of Lilly Pharmaceuticals, shaken well insulin vial, $5.0 \mathrm{~mL}$ taken, digested according to Ahmed method(Ahmed, et al., 2010), the resulting solution transferred quantitatively to $25 \mathrm{~mL}$ volumetric flask and filled with deionized water to the mark.

\section{Sample collection}

Pharmaceutical samples (tablets and capsules) of different companies were collected and insulin vial from the local pharmacy of Misan province. Samples (tablets and capsules) were homogenized with mortar.

\section{Result and Discussion}

\section{Optimization of the experimental parameters}

\section{Absorption spectra}

The UV-VIS absorption spectra of the zinc- 8HQ chelate was shown in Fig.2, acquired from 350-450 nm with a maximum absorbance $384 \mathrm{~nm}$ and an average molar absorptivity $\left(0.01578 \times 10^{3} \mathrm{~L}_{\mathrm{mol}} \mathrm{m}^{-1} \mathrm{~cm}^{-1}\right)$. Free ligand 8 -HQ spectra was shown in Fig. 3 acquire from $270-450 \mathrm{~nm}$ with maximum absorbance $316 \mathrm{~nm}$ at room temperature. The 
absorption peak of the $\mathrm{Zn}-8 \mathrm{HQ}$ chelate shifted to long wavelength, as a result of a charge transfer from the metal to the ligand (MLCT band) (Zhong, et al., 2008).

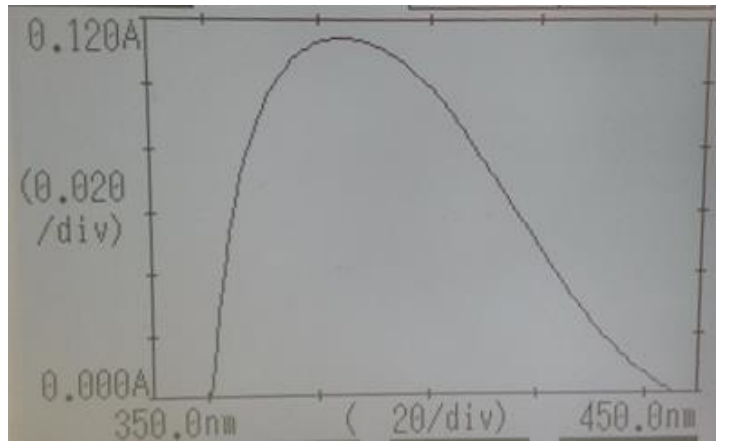

Figure 2. Absorbance spectra of Zn-8HQ chelate $\left(\lambda_{\max } 384 \mathrm{~nm}\right)$

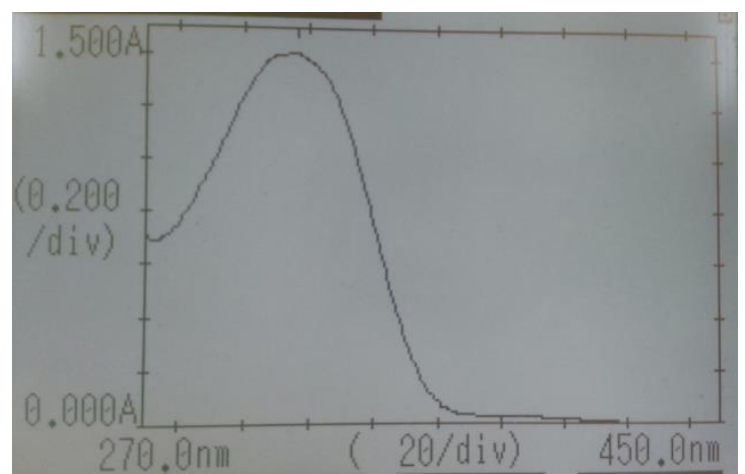

Figure 3. Absorbance spectra of the reagent $8-\mathrm{HQ} 2 \times 10^{-3} \mathrm{M}\left(\lambda_{\max } 316 \mathrm{~nm}\right)$

\section{Effect of solvent}

Different volumes $(0-8 \mathrm{~mL})$ of ethanol were added to fixed concentration of zinc ions as shown in Fig.4 and the absorbance was measured according to the general procedure. Maximum absorbance was appeared in $10 \%(\mathrm{v} / \mathrm{v})$ ethanol / water medium, $10 \%$ ethnol solution was used in the determination procedure.

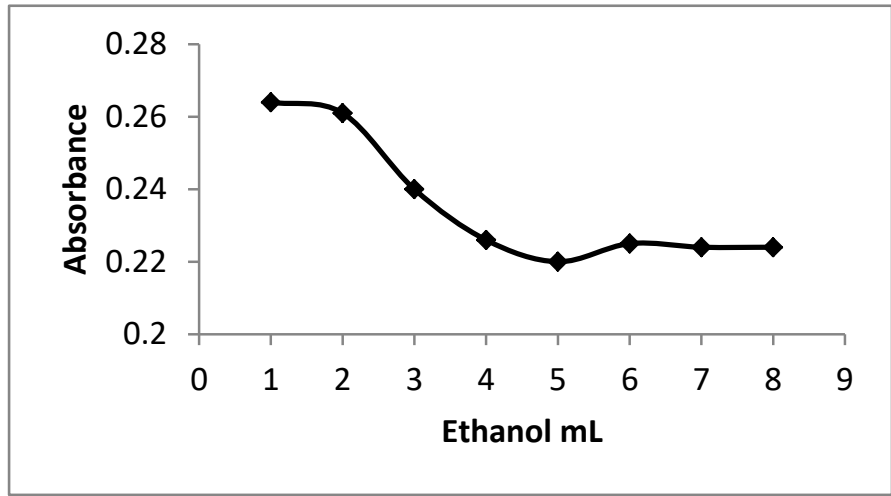

Figure 4. Effect of the ethanol on the absorbance of Zn- 8HQ chelate

\section{Effect of sulfuric acid concentration}

The variation of the absorbance was appeared after the addition of (0.1-1.0 mL) of 0.0001 M sulfuric acid at room temperature $\left(25 \pm 5 \mathrm{C}^{\circ}\right)$ as shown in Fig.5. For all the following measurements $0.6 \mathrm{~mL}$ of $0.0001 \mathrm{M}$ diluted sulfuric acid solution was added. 


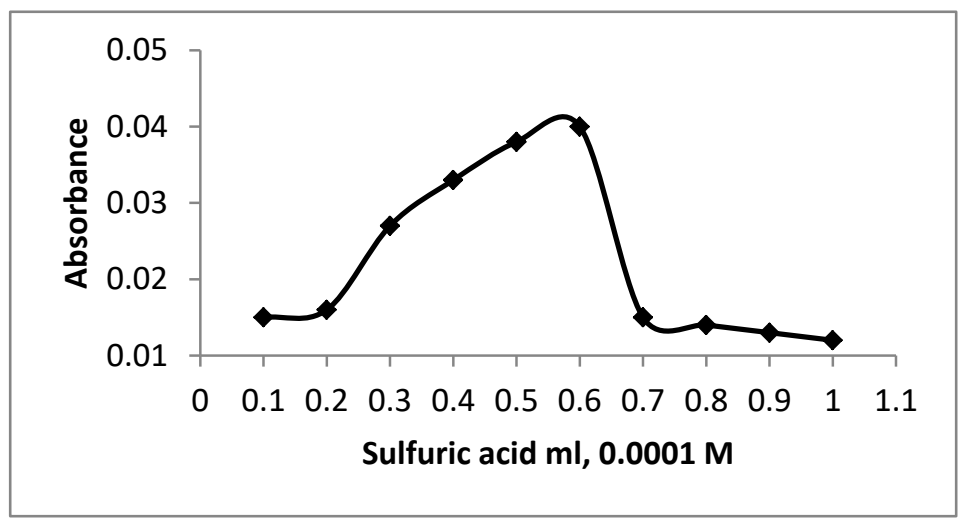

Figure 5. Effect of the sulfuric acid on the absorbance of Zn-8HQ chelate

\section{Effect of the reaction time}

The reaction is very fast. A stable maximum absorbance was obtained during interval time (2-16 minutes) as shown in Fig. 6, just after dilution within 15 minutes all subsequent measurements was adjusted.

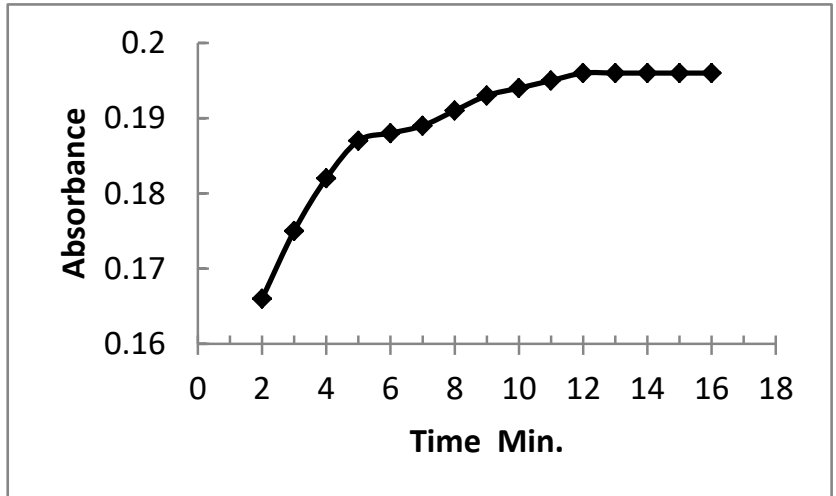

Figure 6. Effect of time on the absorbance of $\mathrm{Zn}-8 \mathrm{HQ}$ chelate

\section{Effect of the 8-HQ reagent concentration}

Different molar of 8-HQ were added to a fixed zinc ion $(1 \mu \mathrm{g} / \mathrm{mL})$ and the absorbance was measured according to the general procedure as shown in Fig. 7. The effect of changeable reagent concentration was noticed. For all following measurements, $5.5 \mathrm{~mL}$ of $1 \times 10^{-5} \mathrm{M} 8 \mathrm{HQ}$ reagent was added.

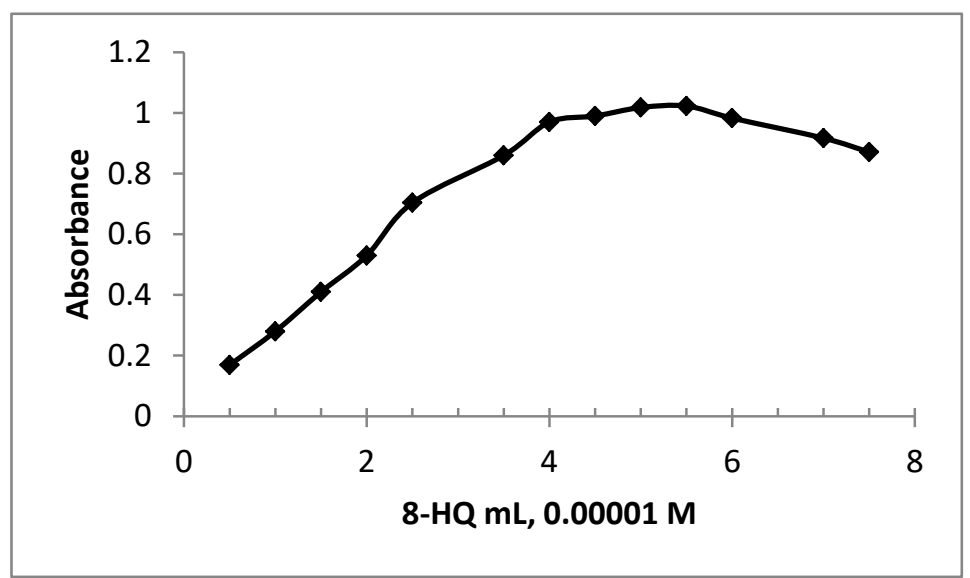

Figure 7. Effect of reagent on the absorbance of Zn-8HQ chelate

\section{Method validation}

System suitability

Standard solutions $(1.0-5.0 \mu \mathrm{g} / \mathrm{mL})$ were prepared by using zinc working standard (1.0 $\mu \mathrm{g} / \mathrm{mL})$. System suitability 
parameters were evaluated and found to be within the limits. The function of the system suitability test was to make sure that the complete testing system (including instrument, reagent and analyte) is suitable for proposed application. The relative standard deviation RSD\% for five absorbance reading of each zinc standard solution is available in Table 1.

Table 1. Evaluation of the spectrophotometric system suitability of zinc analysis

\begin{tabular}{c|c|c|c|c|c|c|c}
\hline Sr. No & $\begin{array}{c}\text { Zinc standard } \\
\mu \mathrm{g} / \mathrm{ml}\end{array}$ & \multicolumn{5}{|c|}{ Five absorbance reading } & RSD\% \\
\hline 1 & 1.0 & 0.024 & 0.025 & 0.024 & 0.024 & 0.025 & 1.004 \\
\hline 2 & 2.0 & 0.053 & 0.052 & 0.053 & 0.052 & 0.051 & 0.717 \\
\hline 3 & 3.0 & 0.077 & 0.077 & 0.078 & 0.077 & 0.078 & 0.316 \\
\hline 4 & 4.0 & 0.010 & 0.090 & 0.011 & 0.011 & 0.010 & 0.373 \\
\hline 5 & 5.0 & 0.121 & 0.122 & 0.121 & 0.121 & 0.122 & 0.202 \\
\hline
\end{tabular}

Acceptance criteria $=$ The RSD\% for zinc absorbance reading should not be further than $2.0 \%$

\section{Linearity}

Linearity was evaluated for the spectrophotometric and the flame atomic absorption methods through a graphical representation of concentration versus absorbance. The absorbance was linear and following Beer's law, the concentration of zinc ion was in the range $(1-5 \mu \mathrm{g} / \mathrm{mL})$ at $384 \mathrm{~nm},(0.1-1.5 \mu \mathrm{g} / \mathrm{mL})$ at $213.9 \mathrm{~nm}$ passing through the origin $\left(\mathrm{R}^{2}=0.9960\right),\left(\mathrm{R}^{2}=0.9985\right)$ for spectrophotometric and flame atomic absorption methods respectively as shown in Fig.8 and Fig.9.The operating parameters of flame atomic absorption for zinc are summarized in Table 2.

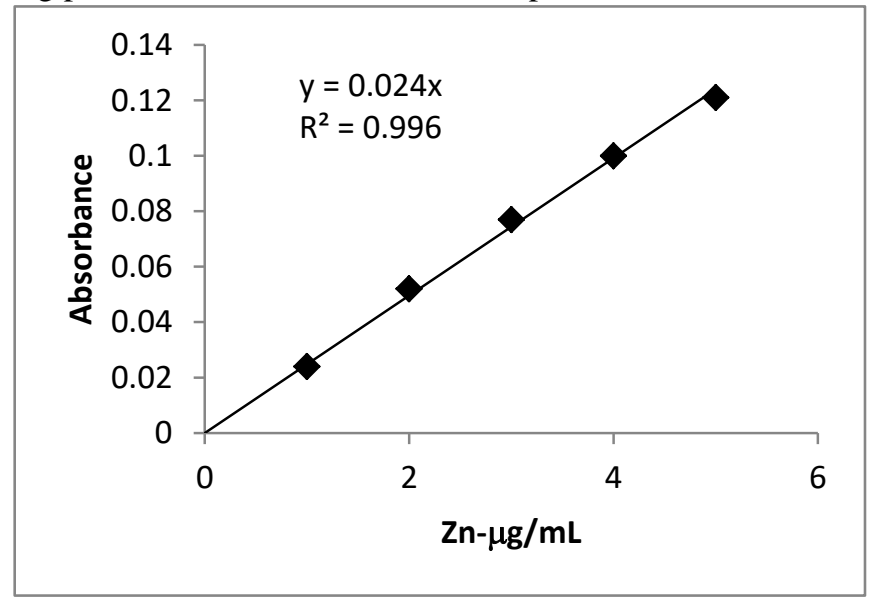

Figure 8 . Calibration graph $(1-5 \mu \mathrm{g} / \mathrm{mL})$ of Zinc by spectrophotometric method

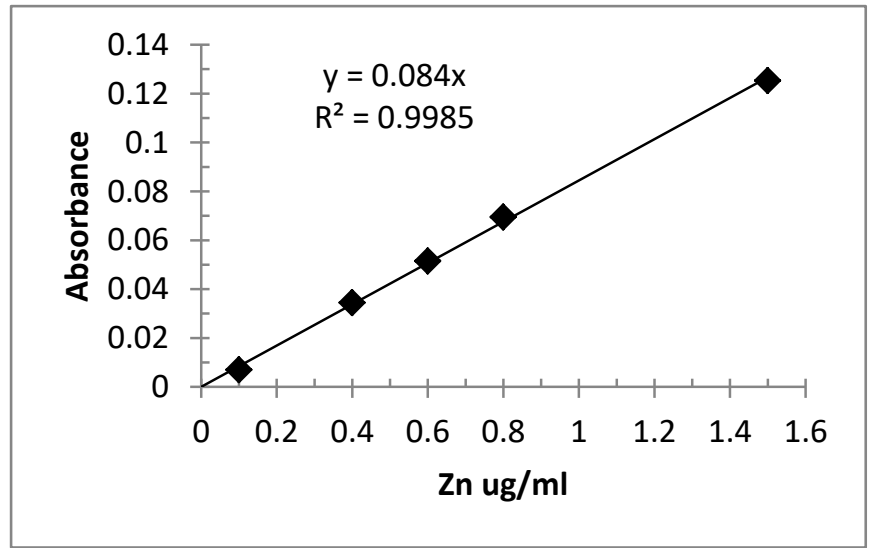

Figure 9. Calibration graph $(0.1-1.5 \mu \mathrm{g} / \mathrm{mL})$ of Zinc by flame atomic absorption method 
Table 2. Operating parameters of flame atomic absorption for zinc

\begin{tabular}{c|c|c|c|c}
\hline Element & Wave length $\mathrm{nm}$ & Slit width $(\mathrm{nm})$ & HCL amp current $(\mathrm{mA})$ & Flame \\
\hline Zinc & 213.9 & 0.2 & 5.0 & Air / acetylene \\
\hline
\end{tabular}

The optimum analytical parameters are summarized in Table 3 shows the required data for obtaining the calibration curve, slop, linear regression equation and the regression coefficient.

Table 3. Optical characteristic of the spectrophotometric method and the flame atomic absorption method

\begin{tabular}{l|l|l}
\hline \multicolumn{1}{c|}{ Parameter } & $\begin{array}{l}\text { Spectrophtometric } \\
\text { method }\end{array}$ & $\begin{array}{l}\text { Flame atomic absorption } \\
\text { method }\end{array}$ \\
\hline$\lambda_{\max }$ & $384 \mathrm{~nm}$ & $213.9 \mathrm{~nm}$ \\
\hline Beer,s law limits $(\mu \mathrm{g} / \mathrm{mL})$ & $1-5 \mu \mathrm{g} / \mathrm{mL}$ & $0.1-1.5 \mu \mathrm{g} / \mathrm{mL}$ \\
\hline Slop & 0.024 & 0.084 \\
\hline Regression equation & $\mathrm{y}=0.024 \mathrm{x}$ & $\mathrm{y}=0.084 \mathrm{x}$ \\
\hline Limit of detection $(\mu \mathrm{g} / \mathrm{mL})$ & 0.381 & 0.216 \\
\hline Limit of quantification $(\mu \mathrm{g} / \mathrm{mL})$ & 1.156 & 0.655 \\
\hline Regression coefficient $\left(\mathrm{R}^{2}\right)$ & 0.9960 & 0.9985 \\
\hline $\boldsymbol{\varepsilon}$ Molar absorptivity $\left(\mathrm{L} . \mathrm{mol}^{-1} \cdot \mathrm{cm}^{-1}\right)$ & $0.01578 \times 10^{3}$ & $0.00514 \times 10^{3}$ \\
\hline
\end{tabular}

\section{Accuracy}

To provide additional support to the accuracy of the method, different standard concentrations of zinc were added to known concentration of the samples and the total concentration were determined by using the proposed method ( $\mathrm{n}=5$ ).

The recovery $\%=\left[\left(C_{t}-C_{s}\right) / C_{a}\right] \times 100$, where $C_{t}$ is the total zinc concentration after standard addition, $C_{s}$ zinc concentration in the samples, $\mathrm{C}_{\mathrm{a}}$ zinc concentration added to the samples. Capsule-1, tablet-2, tablet-3, capsule-4, capsule-5 and Insulin vial, containing $(13 \mathrm{mg}),(20 \mathrm{mg}),(40 \mathrm{mg}),(50 \mathrm{mg}),(50 \mathrm{mg})$ and $(0.025 \mathrm{mg})$ of labeled zinc respectively as shown in Table 4.

Table 4. Percentage recovery of zinc concentration in samples for accuracy

\begin{tabular}{l|c|c|c|c}
\hline \multirow{2}{*}{ Sample } & Zinc added & Total zinc & Total zinc found & \multirow{2}{*}{ Recovery \% } \\
\cline { 2 - 5 } & $(\mathrm{mg} / \mathrm{mL})$ & $(\mathrm{mg} / \mathrm{mL})$ & $(\mathrm{mg} / \mathrm{mL})$ & \\
\hline Capsule -1 & 0.1 & 2.7 & 2.666 & 98.00 \\
\hline Tablet -2 & 0.1 & 0.12605 & 0.12501 & 98.96 \\
\hline Tablet -3 & 0.1 & 2.00476 & 1.99465 & 99.91 \\
\hline Capsule -4 & 0.1 & 0.2488 & 0.2463 & 97.50 \\
\hline Capsule-5 & 0.1 & 7.6923 & 7.6185 & 98.50 \\
\hline Insulin vial & 0.1 & 1.1 & 1.0859 & 99.30 \\
\hline
\end{tabular}

\section{Sensitivity of the method}

The LOD and LOQ are the limit of detection and limit of quantification respectively of zinc by the proposed methods were determined using calibration standard. LOD and LOQ were calculated as $3.3 \sigma / \mathrm{s}$ and $10 \mathrm{\sigma} / \mathrm{s}$ respectively, where $\mathrm{s}$ is the slop of the calibration curve and $\sigma$ the standard deviation of the blank $(n=5)$. LOD and LOQ were found to be $(0.381,0.216 \mu \mathrm{g} / \mathrm{ml})$ and $(1.156,0.655 \mu \mathrm{g} / \mathrm{ml})$ for the proposed method and the standard method respectively as shown in Table 3.

\section{Assay of formulation}

The mean value of zinc in drug tablet, capsule and insulin vial samples $12.83 \mathrm{mg}, 19.69 \mathrm{mg}, 39.79 \mathrm{mg}, 49.97 \mathrm{mg}, 48.88$ $\mathrm{mg}$ and $0.0245 \mathrm{mg}$ for spectrophotometric method and $12.91 \mathrm{mg}, 19.92 \mathrm{mg}, 39.62 \mathrm{mg}, 49.95 \mathrm{mg}, 49.56 \mathrm{mg}$ and $0.024625 \mathrm{mg}$ for standard method respectively. The purity of zinc was calculated $(1.73,3.25,4.73,18.60,18.80 \mathrm{w} / \mathrm{w} \%$ and $4.98 \mathrm{mg} / \mathrm{L})$ for spectrophotometric method and $(1.74,3.28,4.71,18.59,19.06 \mathrm{w} / \mathrm{w} \%)$ for standard method respectively as shown in Table 5. 
Table 5. Assay of formulation

\begin{tabular}{l|c|c|c|c|c}
\hline \multicolumn{1}{c|}{ Sample } & $\begin{array}{c}\text { Label to } \\
\text { content }\end{array}$ & $\begin{array}{c}\text { Direct Method } \\
\text { (Found) } \mathrm{mg}\end{array}$ & Purity & $\begin{array}{c}\text { Standard Method } \\
\text { (Found) } \mathrm{mg}\end{array}$ & $\begin{array}{c}\text { Purity } \\
\text { w/w\% }\end{array}$ \\
\hline Capsule -1 & $13.00 \mathrm{mg}$ & 12.83 & $1.73 \mathrm{w} / \mathrm{w} \%$ & 12.91 & $1.74 \%$ \\
\hline Tablet -2 & $20.00 \mathrm{mg}$ & 19.69 & $3.25 \mathrm{w} / \mathrm{w} \%$ & 19.92 & $3.28 \%$ \\
\hline Tablet -3 & $40.00 \mathrm{mg}$ & 39.79 & $4.73 \mathrm{w} / \mathrm{w} \%$ & 39.62 & $4.71 \%$ \\
\hline Capsule -4 & $50.00 \mathrm{mg}$ & 49.97 & $18.60 \mathrm{w} / \mathrm{w} \%$ & 49.95 & $18.59 \%$ \\
\hline Capsule -5 & $50.00 \mathrm{mg}$ & 48.88 & $18.80 \mathrm{w} / \mathrm{w} \%$ & 49.56 & $19.06 \%$ \\
\hline Insulin vial & $0.025 \mathrm{mg}$ & 0.0245 & $4.98 \mathrm{mg} / \mathrm{L}$ & 0.024625 & $4.985 \mathrm{mg} / \mathrm{L}$ \\
\hline
\end{tabular}

\section{Effect of foreign cations}

A number of divalent cations were studied for their possible interference in the determination of $\mathrm{Zn}$ (II) in a pharmaceutical samples under the optimum conditions. The criterion for an interference (Ojeda, et al., 1987) was an absorbance value varying by more than 5\% from the estimated value for zinc (II) alone. Interference from theses cations are probably due to the complex formation with 8-hydroxyquinoline, the greater tolerance limits for these cations can be achieved by using several masking agents. Tolerance limits for the determination of $1 \mu \mathrm{g} / \mathrm{mL}$ zinc (II) in the concentrations below $16.42 \mu \mathrm{g} / \mathrm{mL}$ Co (II), $82.12 \mu \mathrm{g} / \mathrm{mL}$ Cd(II), $13.14 \mu \mathrm{g} / \mathrm{mL}$ Pb(II), $93.85 \mu \mathrm{g} / \mathrm{mL} \mathrm{Ni(II),} 59.72 \mu \mathrm{g} / \mathrm{mL}$ $\mathrm{Mg}(\mathrm{II}), 8.11 \mu \mathrm{g} / \mathrm{mL} \mathrm{Ca}(\mathrm{II}), 109.5 \mu \mathrm{g} / \mathrm{mL} \mathrm{Ba}(\mathrm{II})$, both $\mathrm{Fe}$ (II) and $\mathrm{Cu}(\mathrm{II})$, however have $25.27 \mu \mathrm{g} / \mathrm{mL}$ and the concentration of $\mathrm{Mn}(\mathrm{II})$ and $\mathrm{Sn}(\mathrm{II})$ is $50.53 \mu \mathrm{g} / \mathrm{mL}$.

\section{Conclusion}

The method using 8-hydroxyquinoline as a spectorophotometric reagent for zinc determination is cheap and simple also can be used in each laboratory. The zinc-8HQ complex formed is stable and shows a good sensitivity. This proposed method was successfully applied for zinc determination in pharmaceutical samples and the results shows a good agreement with certified values and with results obtained by flame atomic absorption method, $\mathrm{t}$-test, $\mathrm{t}_{\mathrm{tab} .}=2.571>\mathrm{t}_{\mathrm{cal}}=$ 0.3231 at $95 \%$ confidence level.

\section{Acknowledgment}

The authors would like to acknowledgment the chemistry department / college of science, Misan University for their support in order to complete all the needed requirements.

\section{Conflict of interest}

All authors have declared that there is no conflict of interests including any financial, personal or other relationships with other people or organizations that can influence their work.

\section{References}

Ahmed, M. J., Hoque, M. R., Khan, A. S. M. S. H., \& Bhattacharjee, S. C. (2010). A simple spectrophotometric method for the determination of aluminum in some real, environmental, biological, soil and pharmaceutical samples using 2-hydroxynaphthaldehydebenzoylhydrazone. Eurasian. J. Anal. Chem., 5, 1-15.

Ata, S., Wattoo, F. H., Ahmed, M., Wattoo, M. H. S., Tirmizi, S. A., \& Wadood, A. (2015). A method optimization study for atomic absorption spectrophotometric determination of total zinc in insulin using direct aspiration technique. Alexandria Journal of Medicine, 5l(1), 19-23. https://doi.org/10.1016/j.ajme.2014.03.004

Bhalotra, A., \& Duri, B. K. (1999). Trace determination of zinc in standard alloys environmental and pharmaceutical samples by fourth derivative spectrophotometry using 1-2-(thiazolylazo)-2- naphtol as reagent and ammonium tetraphenylborate supportet on naphtalene as adsorbent. Talanta., 49, 485-493. https://doi.org/10.1016/S0039-9140(99)00013-2

Emily, H. (2004). Zinc deficiency, DNA damage and cancer risk. The Journal of Nutritional Biochemistry, 15(10), 572-578. https://doi.org/10.1016/j.jnutbio.2004.07.005

Favier, M., \& Hininger-Favier, I. (2005). Zinc and pregnancy. Gynecologie Obstetrique and Fertilite, 33(4), 253-258. https://doi.org/10.1016/j.gyobfe.2005.03.011

Jansen, J., Karges, W., \& Rink, L. (2009). Zinc and diabetes - clinical links and molecular mechanism. The Journal of Nutritional Biochemistry, 20(6), 399-417. https://doi.org/10.1016/j.jnutbio.2009.01.009 
Korn, M., Ferreira, A. C., Teixeira, L. S. G., \& Costa, A. C. S. (1999). Spectrophotometric determination of zinc Using 7-(4-Nitrophenylazo)-8-hydroxyquinoline-5-sulfonic acid. J. Braz. Chem. Soc., 10, 46-50. https://doi.org/10.1590/S0103-50531999000100008

Kumar, A. (1997). Determination of zinc and manganese by differential pulse polorographi technique. Bull. Electrochem., 13, 209-213.

Manciri, M. A., \& Zuanon-Netto (1998). Determination of digoelements in paranteral formulations by planar chromatography and spectrophotometry J. Drug Der. Ind. Pharm., 24(2), 109-114. https://doi.org/10.3109/03639049809085595

Maret, W., \& Sandstead, H. (2006). Zinc requirements and the risks and benefits of zinc supplementation. Journal of Trace Elements in Medicine and Biology, 20(1), 3-18. https://doi.org/10.1016/j.jtemb.2006.01.006

Neto L. C., Bacci, M. R., Sverzutt, L. C., Costa, M. G., Alves, B. C. A., \& Fonseca, F. L. (2016). The role of zinc in chronic kidney disease patients on hemodialysis: A systematic review. Health, 8(4), 344-352. https://doi.org/10.4236/health.2016.84036

Ojeda, C. B., Torres, A. G., Rojas, F. S., \& Pavon, J. M. C. (1987). Flurometric determination of trace amount of gallium in biological tissues. Analyst., 112, 1499-1501. https://doi.org/10.1039/AN9871201499

Reddy, S., Adi, N., Reedy, K. J., Duk, L. K., \& Reedy, A. V. (2016). Evaluation of 2,6-diacetylpyridinebis-4-phenyl-3-thiosemicarbazone as complexing reagent for zinc in food and environmental samples. Journal of Saudi Chemical Society, 20, S271-S279. https://doi.org/10.1016/j.jscs.2012.11.004

Sabel, C. E., Neureuther, J. M., \& Siemann, S. (2010). A spectrophotometric method for the determination of zinc, copper, and cobalt ions in metalloproteins using zincon.Analytical Biochemistry, 397(2), 218-226. https://doi.org/10.1016/j.ab.2009.10.037

Siberry, G. K., Ruff, A. J., \& Black, R. (2000). Zinc and human immunodeficiency virus infection; Nutrition Research, 22(4), 527-538. https://doi.org/10.1016/S0271-5317(02)00364-0

Sołtyk, K., Łozak, A., Warowna-Grze kiewicz, M., \& Fijałek, Z. (2000). The AAS, ICP-MS, and electrochemical determination of zinc in selected pharmaceutical preparations. Acta. Pol. Pharm., 57(4), 261-266.

Takeda, A. (2000). Movement of zinc and its functional significance in the brain. Brain Research Reviews, 34(3), 137-148. https://doi.org/10.1016/S0165-0173(00)00044-8

Tate, D. J., Miceli, M. V., \& Newsome, D. A. (1999). Zinc protects against oxidative damage in cultured human retinal pigment epithelial cells. Free Radical Biologv and Medicine, 26(5-6), 704-713. https://doi.org/10.1016/S0891-5849(98)00253-6

Tokimoto, T., Tsukahara, S., \& Watara, H. (2003). Kinetic study of fast complexation of zinc (II) with 8- quinolinol and 5-octyloxymethyl-8-quinolinol at 1-butanol/water interface by two-phase sheath flow/laser-induced. Bull. Chem. Soc. Jpn., 76, 1569-1576. https://doi.org/10.1246/bcsj.76.1569

Williams, R. J. (1984). Zinc: what is its role in biology? Endeavour., 8(2), 65-70. https://doi.org/10.1016/0160-9327(84)90040-1

Wittrisch, H., Conradi, S., Rohde, E., \& Vogt, C. (1997). Characterisation of metal complexes of electrophoresis with element sensitive detection. J. Chromat. A, 781, 407-416. https://doi.org/10.1016/S0021-9673(97)00417-2

Yasushi, K., Masahiro, M., Noritake, Y., \& Nobutami, K. N. ((1985). The crystal and molecular structure of anhydrous

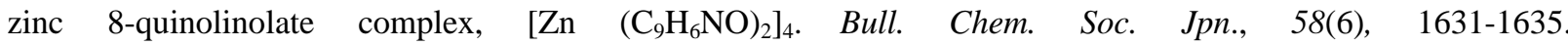
https://doi.org/10.1246/bcsj.58.1631

Zhong, C. F., Wu, Q., Guo, R. F., \& Zhang, H. L. (2008). Synthesis and luminescence properties of polymeric complexes of $\mathrm{Cu}$ (II), $\mathrm{Zn}$ (II) and $\mathrm{Al}$ (III) with functionalized polybenzimidazole containing 8- hydroxyquinoline side group. Optical Materials, 30, 870-875. https://doi.org/10.1016/j.optmat.2007.03.008

\section{Copyrights}

Copyright for this article is retained by the author(s), with first publication rights granted to the journal.

This is an open-access article distributed under the terms and conditions of the Creative Commons Attribution license (http://creativecommons.org/licenses/by/4.0/). 